\title{
ANAEMIA OF RHEUMATOID ARTHRITIS AND IRON THERAPY
}

\author{
BY \\ R. HUME, W. J. C. CURRIE, AND MAUREEN TENNANT \\ From the Departments of Medicine and Biochemistry, Southern General Hospital, Glasgow
}

Richmond, Roy, Gardner, Alexander, and Duthie (1958) reported that anaemia in rheumatoid arthritis could be significantly improved by giving intravenous saccharated oxide of iron. They observed, furthermore, that this response to parenteral iron was not related to the initial iron content of the marrow, the degree of anaemia, the mean corpuscular haemoglobin concentration, the plasma iron level, or the activity of the disease. However, it is apparent from their results that, of 26 patients treated with iron in this way, no more than half achieved a haemoglobin level of 90 per cent. at the end of 3 months. Recently, while treating two anaemic patients with rheumatoid arthritis, we noted that the failure of one of them to respond to parenteral iron was associated with an increase in gamma globulin. This paper reports a more detailed study of this observation.

\section{Methods and Material}

Patients. -44 consecutive patients with rheumatoid arthritis were studied. The diagnosis had been established on clinical, radiological, and serological grounds, and all were undergoing the same basic treatment. Eighteen patients were excluded from the trial: fifteen with a haemoglobin level of $13 \mathrm{~g}$. per cent. or more, two with renal insufficiency, and one with cirrhosis of the liver. Faecal occult blood tests were carried out to detect significant blood loss which might interfere with the response to iron therapy, but no patient was excluded on this ground. The remaining 26 patients, none of whom was receiving steroid therapy, were divided into three groups depending on whether the gamma globulin based on paper electrophoresis was normal or increased. This was a visual interpretation carried out by one of us (M.T.) who did not know the patients and who was unaware a trial was in progress.
Group I.-Eleven patients (10 females and 1 male) who showed no increase in gamma globulin on paper electrophoresis of the serum.

Group II.-Twelve patients (11 females and 1 male) who did show an increase in gamma globulin on paper electrophoresis of the serum.

Group III.-Three patients (all females) who showed no increase in gamma globulin on paper electrophoresis of the serum.

Although it was not possible to measure quantitatively the amount of gamma globulin, the correctness of the interpretation of the electrophoretic strips is supported by the measurement of the total globulins (Tables I and II, overleaf).

The total globulin in each case in Group I was less than 3 g. per cent. (normal 1.8 to 3 ), except Case 10 where the increase is accounted for by an increase in $a_{2}$-globulin. This is illustrated in Fig. 1 (overleaf), which shows some representative electrophoretic strips. The total globulin in each case in Group II was above $3 \mathrm{~g}$. per cent. except Cases 3 and 11. The electrophoretic strips of these two cases (see Fig. 1) show an increase in gamma globulin. Case 1 in Group III had a total globulin of 3.1 g. per cent., accounted for by an increase in $a_{2}$-globulin. Further evidence that the increase in the total globulins was due to an increase in gamma globulin is substantiated by the results of the zinc sulphate turbidity test (Kunkel, 1947). In Groups I and III this measurement was made in ten of the fourteen cases and was $8 \mathrm{u}$ or less (normal 2-8 $u$ ), and in each case in Group II the result was over $10 \mathrm{u}$ (Tables I and II). Of the fifteen patients excluded from the trial with a haemoglobin of $13 \mathrm{~g}$. per cent., only two were considered to have a slight increase in gammaglobulin on electrophoresis.

Groups I and II did not differ with respect to age, duration of disease, sedimentation rate, serum iron, and total iron binding capacity (T.I.B.C.) $(P>0 \cdot 1)$. These results are summarized in Table III (overleaf). 
TABLE I

FINDINGS BEFORE TREATMENT IN GROUPS I AND II

\begin{tabular}{|c|c|c|c|c|c|c|}
\hline \multirow{3}{*}{ Case No. } & \multicolumn{6}{|c|}{ Gamma Globulin } \\
\hline & \multicolumn{3}{|c|}{ Normal Group I (11 Cases) } & \multicolumn{3}{|c|}{ Increased Group II (12 Cases) } \\
\hline & $\begin{array}{c}\text { Albumin } \\
\text { (g. per cent.) }\end{array}$ & $\begin{array}{c}\text { Globulin } \\
\text { (g. per cent.) }\end{array}$ & $\mathrm{Zn} . \mathrm{SO}_{4}$ Turbidity & $\begin{array}{c}\text { Albumin } \\
\text { (g. per cent.) }\end{array}$ & $\begin{array}{l}\text { Globulin } \\
\text { (g. per cent.) }\end{array}$ & $\mathrm{Zn} . \mathrm{SO}_{4}$ Turbidity \\
\hline 1 & $4 \cdot 5$ & $2 \cdot 8$ & 一 & $4 \cdot 7$ & $3 \cdot 9$ & $31 \cdot 6$ \\
\hline 2 & $3 \cdot 8$ & $2 \cdot 5$ & $6 \cdot 8$ & $3 \cdot 4$ & $3 \cdot 7$ & $16 \cdot 0$ \\
\hline 3 & $3 \cdot 7$ & $2 \cdot 9$ & $7 \cdot 0$ & $4 \cdot 3$ & $2 \cdot 5$ & $12 \cdot 4$ \\
\hline 4 & $4 \cdot 0$ & $2 \cdot 7$ & $5 \cdot 8$ & $3 \cdot 9$ & $3 \cdot 4$ & $15 \cdot 2$ \\
\hline 5 & $4 \cdot 2$ & $2 \cdot 6$ & $7 \cdot 6$ & $4 \cdot 7$ & $3 \cdot 1$ & $15 \cdot 6$ \\
\hline 6 & $3 \cdot 9$ & $2 \cdot 5$ & - & $3 \cdot 9$ & $3 \cdot 4$ & $29 \cdot 6$ \\
\hline 7 & $3 \cdot 9$ & $1 \cdot 0$ & - & $4 \cdot 0$ & $3 \cdot 8$ & $26 \cdot 0$ \\
\hline 8 & $4 \cdot 5$ & $1 \cdot 5$ & $8 \cdot 0$ & $4 \cdot 5$ & $3 \cdot 3$ & $17 \cdot 5$ \\
\hline 9 & $4 \cdot 1$ & $2 \cdot 9$ & - & $4 \cdot 2$ & $3 \cdot 4$ & $20 \cdot 4^{*}$ \\
\hline 10 & $3 \cdot 4$ & $3 \cdot 1^{*}$ & $4 \cdot 8$ & $3 \cdot 5$ & $3 \cdot 7$ & $10 \cdot 8$ \\
\hline 11 & $4 \cdot 3$ & 2.9 & $7 \cdot 0$ & $3 \cdot 4$ & $2 \cdot 9$ & $22 \cdot 4$ \\
\hline 12 & - & - & - & $5 \cdot 0$ & $3 \cdot 6$ & $10 \cdot 5$ \\
\hline Mean & $4 \cdot 0$ & $2 \cdot 5$ & $6 \cdot 7$ & $4 \cdot 1$ & $3 \cdot 4$ & $19 \cdot 0$ \\
\hline
\end{tabular}

* Increase due to $\alpha_{2}$ globulin.

TABLE II

FINDINGS BEFORE TREATMENT IN GROUP III

\begin{tabular}{c|c|c|c}
\hline Case No. & \multicolumn{1}{|c|}{ Normal Gamma Globulin Group III } \\
\cline { 2 - 3 } & $\begin{array}{c}\text { Albumin } \\
\text { (g. per cent.) }\end{array}$ & $\begin{array}{c}\text { Globulin } \\
\text { (g. per cent.) }\end{array}$ & $\begin{array}{c}\text { Zn.SO } \\
\text { Turbidity }\end{array}$ \\
\hline 1 & $3 \cdot 4$ & $3 \cdot 1^{*}$ & $4 \cdot 5$ \\
\hline 2 & $4 \cdot 5$ & $1 \cdot 5$ & $8 \cdot 0$ \\
\hline 3 & $4 \cdot 3$ & $2 \cdot 7$ & $6 \cdot 2$ \\
\hline
\end{tabular}

* Increase due to $\alpha_{2}$ globulin.
Marrow Iron.-Staining was performed before treatment in four patients in Group I; it was absent in three and of normal amount in one. In Group II six patients were examined for narrow iron; it was absent in one, reduced in two, normal in two, and present in excess in one.

Activity and Functional Capacity were graded according to the criteria of Duthie, Brown, Knox, and Thompson (1957) and was not significantly different in either group.

TABLE III

GENERAL COMPARISON OF GROUPS I AND II

\begin{tabular}{|c|c|c|c|c|c|c|c|c|c|c|c|}
\hline \multirow{2}{*}{ Group } & \multirow{2}{*}{$\begin{array}{c}\text { No. of Cases } \\
11 \\
\end{array}$} & \multicolumn{2}{|c|}{ Age (yrs) } & \multicolumn{2}{|c|}{$\begin{array}{c}\text { Duration of } \\
\text { Rheumatoid Arthritis } \\
\text { (yrs) }\end{array}$} & \multicolumn{2}{|c|}{$\begin{array}{c}\text { Erythrocyte } \\
\text { Sedimentation Rate } \\
(\mathrm{mm} . / \mathrm{hr})\end{array}$} & \multicolumn{2}{|c|}{$\begin{array}{l}\text { Serum Iron } \\
(\ell \text { g. per cent. })\end{array}$} & \multicolumn{2}{|c|}{$\begin{array}{l}\text { Total Iron Binding } \\
\text { Capacity ( } \mu \mathrm{g} \text {. per cent.) }\end{array}$} \\
\hline & & $50 \cdot 4$ & $\pm 15 \cdot 5$ & $8 \cdot 3$ & $\pm 5 \cdot 3$ & $52 \cdot 0$ & \pm 32 & $37 \cdot 5$ & $\pm 14 \cdot 6$ & $354 \cdot 6$ & \pm 58.9 \\
\hline II & 12 & $54 \cdot 6$ & $\pm 12 \cdot 1$ & $10 \cdot 5$ & $\pm 6 \cdot 5$ & $68 \cdot 0$ & \pm 26 & $37 \cdot 1$ & $\pm 19 \cdot 2$ & $332 \cdot 3$ & $\pm 69 \cdot 3$ \\
\hline
\end{tabular}




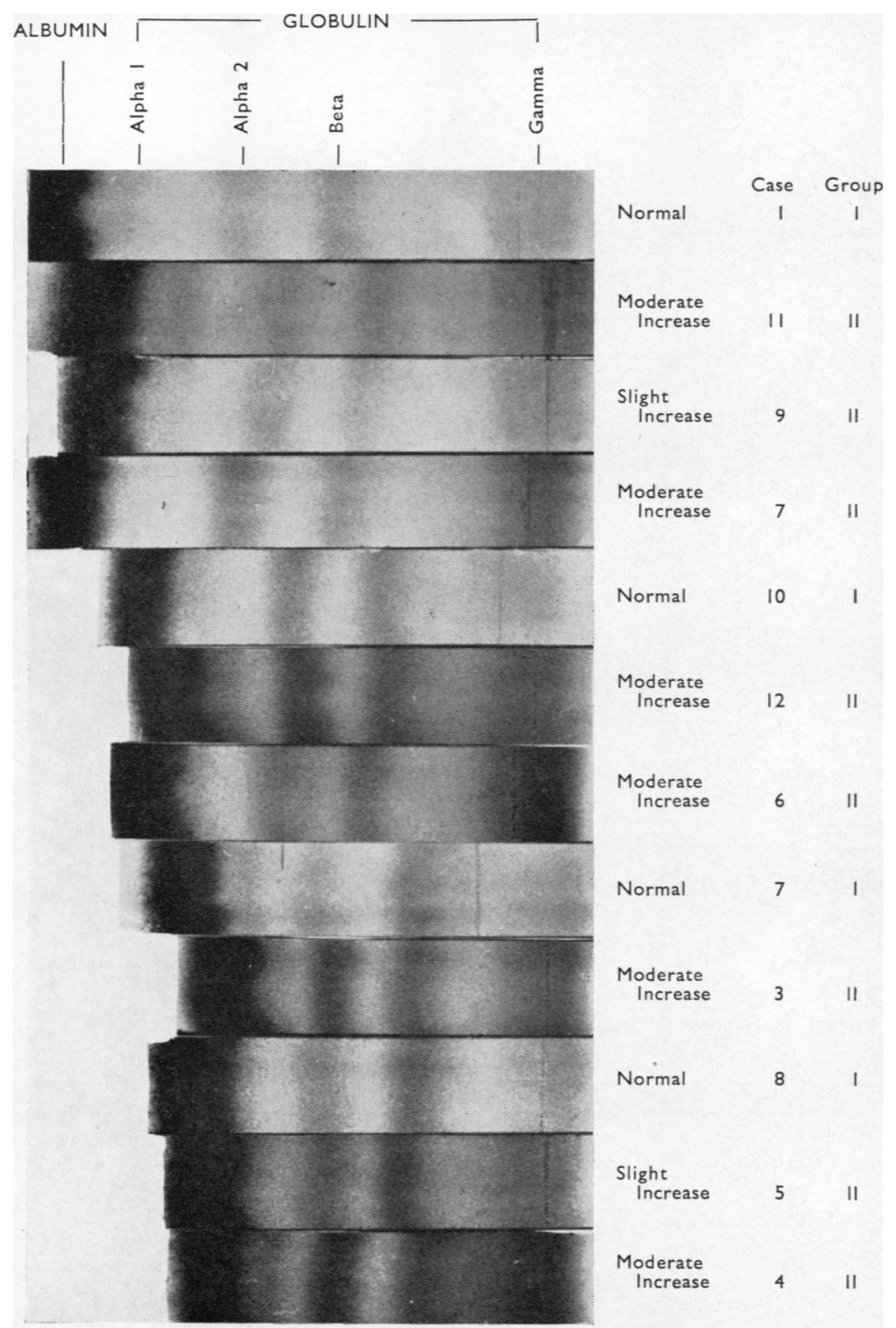

Fig. 1.-Representative electrophoretic strips. Serum Protein Patterns in Rheumatoid Arthritis.

Treatment of Anaemia.-Each patient in Groups I and II was given intramuscularly $100 \mathrm{mg}$. iron dextran (Imferon) daily until a total of one g. had been administered and the response in the anaemia noted (Table IV; Fig. 2, overleaf).

Those in Group III were given oral iron therapy and the response noted (Table $V$, overleaf). Final assessment was made at the end of 3 months when they attended as out-patients.
Paper Electrophoresis of Serum Proteins.-This was carried out according to the method of Martin and Franglen (1954) modified by the staining technique of Jencks, Jetton, and Durrum (1955).

Estimation of Serum Proteins was carried out by the Biuret method using 23 per cent. sodium sulphate for globulin precipitation according to the methods of 
TABLE IV

RESULTS IN GROUPS I AND II AFTER 3 MONTHS

\begin{tabular}{|c|c|c|c|c|c|c|c|c|c|}
\hline \multirow[t]{2}{*}{ Group } & \multirow[t]{2}{*}{$\cdots$} & \multirow[t]{2}{*}{$\cdots$} & \multirow[t]{2}{*}{$\cdots$} & \multirow[t]{2}{*}{$\cdots$} & \multirow[t]{2}{*}{$\cdots$} & \multicolumn{2}{|c|}{ I. Normal Gamma Globulin } & \multicolumn{2}{|c|}{ II. Increased Gamma Globulin } \\
\hline & & & & & & Hb (g. per cent.) & $\begin{array}{l}\text { Packed Cell Volume } \\
\text { (per cent.) }\end{array}$ & Hb (g. per cent.) & $\begin{array}{l}\text { Packed Cell Volume } \\
\text { (per cent.) }\end{array}$ \\
\hline Before Treatment & .. & .. & $\ldots$ & $\ldots$ & $\ldots$ & $10 \cdot 3 \pm 1 \cdot 3$ & $33 \cdot 6 \pm 3 \cdot 2$ & $10 \cdot 8 \pm 1.0$ & $34 \cdot 1 \pm 2 \cdot 4$ \\
\hline After Treatment* & . & . & . & . & .. & $13 \cdot 7 \pm 0 \cdot 7$ & $40 \cdot 9 \pm 2 \cdot 1$ & $11 \cdot 6 \pm 1 \cdot 0$ & $36 \cdot 0 \pm 3 \cdot 2$ \\
\hline Mean Increase & . & $\cdots$ & . & $\cdots$ & $\ldots$ & $3 \cdot 37$ & $7 \cdot 27$ & 0.77 & $1 \cdot 92$ \\
\hline
\end{tabular}

* At 3-month follow-up after $1 \mathrm{~g}$. intramuscular iron dextran. Means expressed with one standard deviation.

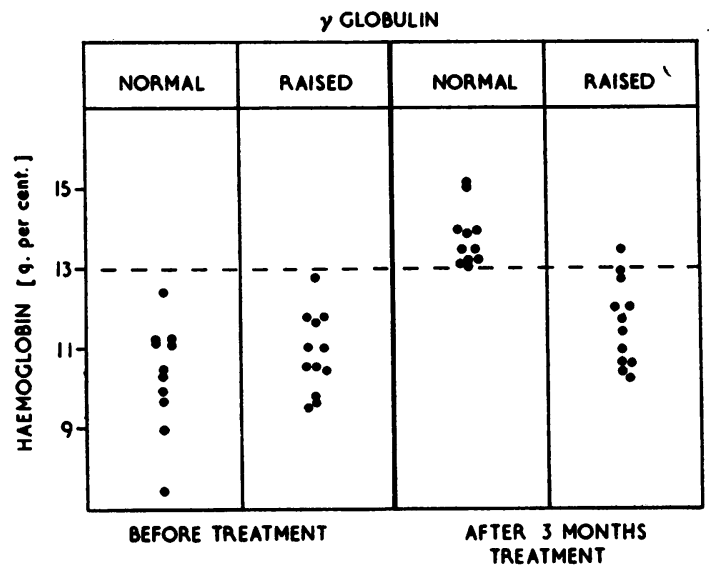

Fig. 2.-Difference in response to parenteral iron therapy in the presence or absence of increased gamma globulin.

TABLE V

EFFECT OF ORAL IRON THERAPY IN THREE CASES WITH NORMAL GAMMA GLOBULIN LEVELS

\begin{tabular}{|c|c|c|c|c|}
\hline \multirow{2}{*}{$\begin{array}{l}\text { Case } \\
\text { No. }\end{array}$} & \multicolumn{2}{|c|}{ Before Treatment } & \multicolumn{2}{|c|}{ After Treatment } \\
\hline & $\begin{array}{l}\text { Hb. } \\
\text { (g. per cent.) }\end{array}$ & $\begin{array}{c}\text { Packed Cell } \\
\text { Volume } \\
\text { (per cent.) }\end{array}$ & $\begin{array}{l}\text { Hb. } \\
\text { (g. per cent.) }\end{array}$ & $\begin{array}{c}\text { Packed Cell } \\
\text { Volume } \\
\text { (per cent.) }\end{array}$ \\
\hline 1 & $8 \cdot 9$ & 28 & $13 \cdot 2$ & 40 \\
\hline 2 & $11 \cdot 2$ & 34 & $13 \cdot 5$ & 40 \\
\hline 3 & $11 \cdot 2$ & 37 & $13 \cdot 5$ & 40 \\
\hline
\end{tabular}

Kingsley (1940) and Gornall, Bardawill, and David (1949) (Globulin normal range $1 \cdot 8$ to $3 \mathrm{~g}$. per cent.).

Zinc Sulphate Turbidity was estimated by the method of Kunkel (1947) (normal range 2-8 u).

Serum Iron and Total Iron Binding Capacity (TIBC) were measured by the method of Ramsay (1957) (normal range: serum iron $60-200 \mu \mathrm{g} . / 100 \mathrm{ml}$.; TIBC 300-340 $\mu \mathrm{g} . / 100 \mathrm{ml}$.).

Erythrocyte Sedimentation Rate (E.S.R.) was measured by the Westergren method at the end of one hour.
Routine Haematological Measurements were made according to Dacie (1956).

\section{Results}

Haemoglobin (Table IV; Fig. 2).-Before treatment with intramuscular dextran the mean haemoglobin level of the two groups showed no statistical difference. Assessment at 3 months, however, revealed that the haemoglobin of Group I had increased by $3.37 \mathrm{~g}$. per cent. and that in each case the haemoglobin was $13 \mathrm{~g}$. per cent. or above, while the mean haemoglobin of Group II had risen by only 0.77 g. per cent., and only one patient had a haemoglobin greater than $13 \mathrm{~g}$. per cent., although two others were above $12.5 \mathrm{~g}$. per cent. This difference in the rise in $\mathrm{Hb}$ (before and after treatment) is statistically highly significant $(P<0.01)$.

Packed Cell Volume (P.C.V.) (Table IV).-Before treatment there was no statistically significant difference between Groups I and II in the mean P.C.V. ( $P>0 \cdot 1)$. After 3 months, however, the P.C.V. of Group I had risen by $7 \cdot 27$ per cent., while that of Group II had risen by only 1.92 per cent. This difference before and after treatment is statistically highly significant $(P<0 \cdot 01)$.

\section{Discussion}

The results of this investigation indicate that treatment of anaemia in rheumatoid arthritis with iron will be successful when the electrophoretic pattern of the serum reveals a normal gamma globulin and that in the presence of an increased level of gamma globulin no significant effect is likely to be produced. Furthermore, the route of administration of the iron, whether oral or intramuscular, does not seem to be important provided the same condition is satisfied. This is demonstrated by the satisfactory response to oral iron in the three patients illustrated in Table V. The 
absorption of iron from the gut in rheumatoid arthritis is normal (Richmond and others, 1958). Of the group of eleven patients without a raised gamma globulin pattern each one reached a haemoglobin level of $13 \mathrm{~g}$. per cent. or more (a mean rise of $3.37 \mathrm{~g}$.), while only one of the twelve patients with raised gamma globulin attained a haemoglobin level of more than $13 \mathrm{~g}$. per cent., the mean rise being only $0.77 \mathrm{~g}$. This difference in response to iron therapy is highly significant $(P<0.01)$.

The same effect is also reflected in the different response of the P.C.V. in the two groups, namely $7 \cdot 27$ and 1.92 per cent. respectively, a highly significant difference $(\mathrm{P}<0 \cdot 01)$.

Further evidence showing the importance of the level of gamma globulin in determining the response to treatment can be seen from the two cases illustrated in Table VI. The anaemia of the first patient failed to respond to intramuscular iron therapy in in the presence of a raised gamma globulin level, but a year later a normal haemoglobin was found when the electrophoretic pattern had returned to normal. The second patient shows the converse, namely a good response to iron when no increase in gamma globulin was apparent and a fall in the haemoglobin a year later coinciding with the appearance of an increase in serum gamma globulin without evidence that iron deficiency had developed.

It seems possible that this relationship may explain the variable results of the administration of iron to patients with rheumatoid arthritis (Sinclair and Duthie, 1949, 1950; Ross, 1950; Jeffrey, 1952, 1953a and b; Millard and Barber, 1956; McCrea, 1958; Richmond and others, 1958).

The finding of a low serum iron and a moderately increased total iron binding capacity in both groups of patients is of interest. It would appear that a low serum iron reflects a likely response to iron therapy only when there is a normal gamma globulin band on serum electrophoresis. In the presence of an increase in gamma globulin, even when iron deficiency is clearly demonstrated by the presence of depleted or absent marrow iron, the response to iron therapy will be only partial. Other factors which might have influenced the result, namely age of patient, duration and severity of disease, functional capacity, and erythrocyte sedimentation rate, appear to bear no relationship to the response to iron therapy.

While the anaemia of Felty's syndrome is primarily due to shortening of the the red cell survival (Hume, Dagg, Fraser, and Goldberg, 1964), the anaemia of rheumatoid arthritis is due mainly to impaired haemoglobin synthesis (Weinstein, 1959) although there is also a mild extracorpuscular haemolytic element (Bunim, 1954; Ebaugh, Peterson, Rodnan and Bunim, 1959; Richmond, Alexander, Potter and Duthie, 1961). Our observations show that lack of response to therapy of the anaemia is associated with an increased gamma globulin. Since histological studies of the marrow of patients with rheumatoid arthritis have shown an increase in plasma cells (Richmond, Gardner, Roy, and Duthie, 1956), and since in certain cases the anaemia of rheumatoid arthritis can be relieved by steroid therapy (Copeman, 1964), it may well be that the increased gamma globulin reflects the presence of an antibody active against marrow cells or against the red cell stimulating hormone, erythroprotein. These two possibilities are being investigated. Since the anaemias of infection, neoplasia, and some refractory anaemias have similar red cell survival and ferrokinetic patterns to those of rheumatoid arthritis, the implications of this study may have a wider application.

TABLE VI

RESULTS OF IRON THERAPY IN TWO CASES

\begin{tabular}{|c|c|c|c|c|c|c|c|c|}
\hline & Case No. & & & & & Hb (g. per cent.) & Packed Cell Volume (per cent.) & Gamma Globulin \\
\hline \multirow{4}{*}{1} & Before Treatment & . & $\cdots$ & . & . & $10 \cdot 5$ & 34 & Increased \\
\hline & $1 \mathrm{mth}$ Follow-up & . & $\cdots$ & $\cdots$ & $\cdots$ & $9 \cdot 4$ & 33 & Increased \\
\hline & 3 mths' Follow-up & . & $\cdots$ & $\cdots$ & $\cdots$ & $10 \cdot 6$ & 35 & Increased \\
\hline & 12 mths' Follow-up & . & $\cdots$ & $\cdots$ & $\cdots$ & $13 \cdot 5$ & 43 & Normal \\
\hline \multirow{4}{*}{2} & Before Treatment & . & $\cdots$ & $\cdots$ & $\cdots$ & $11 \cdot 0$ & 35 & Normal \\
\hline & $1 \mathrm{mth}$ Follow-up & $\cdots$ & . & $\cdots$ & $\cdots$ & $12 \cdot 5$ & 39 & Normal \\
\hline & 3 mths' Follow-up & . & . & $\cdots$ & . & $13 \cdot 9$ & 41 & Normal \\
\hline & 12 mths' Follow-up & .. & .. & .. & .. & $12 \cdot 2$ & 38 & Increased \\
\hline
\end{tabular}




\section{Summary}

Two groups of anaemic patients with rheumatoid arthritis were treated with $1 \mathrm{~g}$. intramuscular iron dextran (Imferon). The groups did not differ with respect to age, sex, duration of illness, erythrocyte sedimentation rate, serum iron, or total iron binding capacity. Group I had a normal level of gamma globulin on paper electrophoresis of the serum and Group II had an increased level. It was found that Group I showed a mean increase in haemoglobin of $3.4 \mathrm{~g}$. per cent. while in Group II the mean increase was only $0.77 \mathrm{~g}$. per cent. $(\mathbf{P}<\mathbf{0 . 0 1})$. This failure of Group II to respond did not appear to be related to the presence or absence of marrow iron. Both groups had a low serum iron. It would appear that a low serum iron indicates a likely response to iron therapy only when the gamma globulin level is normal. The route of administration of iron did not appear to be important, as illustrated by the satisfactory response to oral iron of three further patients.

These observations are discussed in the light of the variable results reported after the administration of iron to patients with rheumatoid arthritis and of the possible autoimmune basis of these variations.

We are indebted to Dr. L. D. W. Scott for his helpful advice and criticism in the preparation of this paper. Our thanks are also due to the Department of Haematology and to the various Physicians and Surgeons who referred patients for study.

\section{REFERENCES}

Bunim, J. J. (1954). Ann. rheum. Dis., 13, 365.

Copeman, W. S. C. (1964). "Textbook of the Rheumatic Diseases", 3rd ed., p. 186. Livingstone, Edinburgh.

Dacie, J. V. (1956). "Practical Haematology", 2nd ed. Churchill, London.

Duthie, J. J. R., Brown, P. E., Knox, J. D. E., and Thompson, M. (1957). Ann. rheum. Dis.. 16, 411.

Ebaugh, F. G., Peterson, R. E., Rodnan, G. P., and Bunim, J. J. (1955). Med. Clin. N. Amer., 39, 489.

Gornall, A. G., Bardawill, C. J., and David, M. M. (1949). J. biol. Chem., 177, 751.

Hume, R., Dagg, J. H., Fraser, T. N., and Goldberg, A. (1964). Ann. rheum. Dis., 23, 267.

Jeffrey, M. R. (1952). Ibid., 11, 162.

- (1953a). Blood, 8, 502.

- (1953b). Brit. med. J., 2, 912.

Jencks, W. J., Jetton, M. R., and Durrum, E. L. (1955). Biochem. J., 60, 205.

Kingsley, G. R. (1940). J. biol. Chem., 133, 731.

Kunkel, H. G. (1947). Proc. Soc. exp. biol. (N.Y.), 66, 217.

McCrea, P. C. (1958). Ann. rheum. Dis., 17, 89.
Martin, N. H., and Franglen, G. T. (1954). J. clin. Path., 7, 87.

Millard, J. B., and Barber, H. S. (1956). Ann. rheum. Dis., $15,51$.

Ramsey, W. N. M. (1957). Clin. chim. Acta, 2, 214.

Richmond, J., Alexander, W. R. M., Potter, J. L., and Duthie, J. J. R. (1961). Ibid., 20, 133.

—-, Gardner, D. L., Roy, L. M. H., and Duthie, J. J. R. (1956). Ibid., 15, 217.

Roy, L. M. H., Gardner, D. L., Alexander, W. R. M., and Duthie, J. J. R. (1958). Ibid., 17, 406.

Ross, D. N. (1950). I Ibid., 9, 358.

Sinclair, R. J. G., and Duthie, J. J. R. (1949). Lancet, $2,646$.

- and Duthie, J. J. R. (1950). Brit. med. J., 2, 1257.

Weinstein, I. M. (1959). Blood, 14, 950.

\section{L'anémie de l'arthrite rhumatismale et la thérapie martiale}

\section{RÉSUMÉ}

Deux groupes de malades anémiques atteints d'arthrite rhumatismale furent traités par $1 \mathrm{~g}$. de fer-dextran (Imferon) intramusculaire. Les deux groupes ne différaient pas entre eux en ce qui concerne l'âge, le sexe, la durée de la maladie, vitesse de la sédimentation globulaire, le fer sérique ou la capacité totale de fixer le fer. Le Groupe I avait un niveau normal de la gamma globuline à l'électrophorèse sur papier du sérum, tandis que dans le Groupe II ce niveau était augmenté. On a trouvé que dans le Groupe I l'hémoglobine s'est élevée en moyenne de $3,4 \mathrm{~g}$. pour cent, mais dans le Groupe II cette augmentation n'était que de $0,77 \mathrm{~g}$. pour cent en moyenne $(P<0,01)$. Cette faible réponse du Groupe II ne semblait pas être liée à la présence ou à l'absence du fer dans la moelle. Le fer sérique était bas dans les deux groupes. Il paraît donc qu'une sidéropénie sérique ne cède à la thérapie martiale que lorsque le niveau de la gamma globuline est normal. La voie par laquelle on administre le fer ne semble pas être importante, car on a obtenu une réponse satisfaisante chez trois autres malades qui avaient reçu leur fer par la voie orale.

On discute ces observations à la lumière des résultats variables rapportés après l'administration du fer aux malades atteints d'arthrite rhumatismale et on pense que ces variations pourraient être liées à l'auto-immunité.

\section{La anemia de la artritis reumatoide y la terapia marcial}

\section{Sumario}

Dos grupos de enfermos anémicos padeciendo de artritis reumatoide fueron tratados con $1 \mathrm{~g}$. de hierrodextran (Imferon) intramuscular. Estos grupos no se distinguían entre sí respecto a la edad, el sexo, la duración de la enfermedad, y la velocidad de la sedimentación eritrocitaria, el hierro sérico o la capacidad total para fijar el hierro. En el Grupo I el nivel de la gamma globulina a la electroforesis sobre papel del suero fué normal y en el Grupo II este nivel fué aumentado. En el Grupo I la sideroterapia produjo un aumento medio de la hemoglobina de un $3,4 \mathrm{~g}$. por ciento, pero sólo de un 0,77 g. ( $P<0,01)$ por ciento en el Grupo II. Esta débil respuesta del Grupo II no pareció relacionarse con 
la presencia o ausencia del hierro en la médula. El hierro sérico fué bajo en ambos grupos. Parece, pues, que la sideropenia sérica sólo responde a la terapia marcial cuando el nivel de la gamma globulina es normal. La vía de administración del hierro no parece importar, ya que una respuesta satisfactoria fué también obtenida en tres otros enfemos que habían recibido su hierro por vía oral.

Se discuten estas observaciones a la luz de los resultados variables relatados después de la administración de hierro a enfermos con artritis reumatoide y se sugiere que pudiera haber aquí una base auto-inmunológica. 